\title{
Exercise-induced cardiac fatigue in low handicap polo horses
}

\author{
Fatiga cardíaca producida por el ejercicio en equinos de polo con bajo rendimiento \\ CAO Bello, CBS Dumont, ARC Barreto-Vianna, EMM Lima* \\ Departamento de Anatomia Veterinária, Faculdade de Agronomia e Medicina Veterinária, Universidade de Brasília, \\ ICC Ala Sul, Campus Darcy Ribeiro, Brasília, Brazil.
}

\begin{abstract}
RESUMEN
El ejercicio físico trae aparejado cambios en el sistema cardiovascular de equinos, pudiendo inducir anormalidades que no son observadas en reposo. Poco se sabe sobre las consecuencias cardíacas del esfuerzo físico intenso realizado por caballos en competencias de polo. El objetivo de este estudio fue identificar cómo se manifiesta la fatiga cardíaca, inducida por el ejercicio en caballos de polo saludables. Fueron evaluados antes y después de la actividad física, 25 equinos de polo sometidos a un partido de entrenamiento. Los resultados demostraron alteración del perfil electrocardiográfico, como arritmia cardíaca, aumento del QTc, alteración en la onda T y elevación del segmento ST. El ecocardiograma indicó reducción en el espesor de la pared de septo interventricular, en sístole, y de la pared libre del ventrículo izquierdo, reducción del volumen sistólico, de la fracción de eyección y fracción de acortamiento. Este resultado sugirió que la actividad física de polo induce la fatiga cardíaca. No fue posible establecer de forma precisa la etiología de estos cambios, así como sus consecuencias a largo plazo.
\end{abstract}

Palabras clave: equino, fisiología del ejercicio, función cardíaca.

\section{SUMMARY}

Physical exercise leads to several changes in the cardiovascular system of horses and may induce abnormalities that are not observed at rest. Little is known about the cardiac effects of intense physical exercise performed by horses in polo competitions. This study aimed at identifying if exerciseinduced cardiac fatigue is observed in healthy polo ponies. We examined 25 equine athletes before and after a training match. The results demonstrated post-exercise electrocardiographic alteration such as cardiac arrhythmia, QTc prolongation, abnormal T waves and ST-segment elevation. The postexercise echocardiogram showed interventricular septum and left ventricle free wall thickness reduction, systolic volume decreased and ejection fraction decreased. These results suggest that polo causes exercise-induced cardiac fatigue. It was not possible to establish accurately the etiology of this abnormality, nor its long-term consequences.

Key words: horse, exercise physiology, cardiac function.

\section{INTRODUCTION}

Physical exercise results in several changes to the cardiovascular system of horses and the best-suited animals stand out by demonstrating improved athletic ability. When activity demands less than maximum cardiac output, it may be difficult to discern subtle or subclinical abnormalities. Such abnormalities are common and may include arrhythmias and abnormal myocardial wall motion during exercise.

In polo horses, Marlin and Allen (1999) demonstrated that the physical effort over a chukker demands high cardiac activity, and for two minutes, a total of ten animals worked above $80 \%$ of the maximal oxygen uptake $\left(\mathrm{VO}_{2 \max }\right)$ and maximum heart rate $\left(\mathrm{HR}_{\max }\right)$, and over four minutes between 50 and $80 \% \mathrm{VO}_{2 \max }$. According to Ferraz et al (2010) horses participating in a training match, high handicap, were subjected to high intensity effort resulting in sizeable transient

Accepted: 14.05.2014.

* Cx Postal 4508, Brasília, DF 70760-701, Brazil; limaemm@unb.br changes in electrolytes and acid-base balance. Holbrook et al (2006) found that systemic metabolic changes may, directly or indirectly, alter cardiovascular function and compromise myocardial integrity.

In endurance horses, exercise-induced cardiac fatigue (EICF), which consists of acute and significant reduction of one or both diastolic and systolic functions of the left ventricle after exercise, has been reported (Amory et al 2010). The impact of EICF is unknown, and has been shown to be transient, resolving 24 hours after exercise and is not associated with a significant increase in some myocardial injury markers. Nevertheless, EICF may affect athletic performance, and influence metabolic disorders. Douglas et al (1987) reported that for human athletes, this condition can also assume clinical importance for those with heart disease or the elderly, who have participated in high performance competitions for many years. Importantly, exercise-induced cardiac fatigue (EIFC) has been mentioned as a potential cause of exercise-induced sudden death in athletes with no previous history of cardiovascular disease (McGavock et al 2002), although its role in equine sudden death has not been explored. 
Little is known about the changes regarding the cardiovascular function induced by intense physical exercise during polo competitions. The purpose of this study was to determine the incidence and magnitude of exercise induced cardiac fatigue (EIFC) in clinically healthy polo player horses (low handicap).

\section{MATERIAL AND METHODS}

This study was approved by the Ethics Committee on Animal Use of the Biological Sciences Institute of the University of Brasilia, protocols 21359/2010 and $52412 / 2010$. Twenty-five horses were used in this study, including 11 males, and 14 females, ranging in age from five to 15 years $(8.6 \pm 3.5)$, weighing from 393.5 to 497 $\mathrm{kg}(427 \pm 29.7)$. Animals were from the Brazilian Army Stud Farm. They were mixed-breed horses, part of the polo squad of the $1^{\text {st }}$ Cavalry Guard, where they underwent the same nutritional management and athletic training for at least one year prior to the study. None of the animals showed abnormalities on routine clinical examination, including cardiac auscultation, and they were within the health standard required by the Team of Veterinary Officers of this regiment.

Animals were evaluated for a regular training period aiming for participation in the Army Polo Championship/2010. The horses we used were team members of the Military Command of the Plateau, considered of low handicap (up to eight goals). The training program consisted of four training matches per week, each animal played only one chukker, i.e., seven minutes per training match. In the period evaluated, the relative air humidity was approximately $43 \%$ and average ambient temperature was $25^{\circ} \mathrm{C}$.

Each horse underwent two electrocardiographic and echocardiographic evaluations at different times. The first was performed before the exercise, on the day that the animals were not trained, that is, they have not performed physical exercise for at least 24 hours, time zero $\left(\mathrm{M}_{0}\right)$. The second assessment (on the same day) was within the period of five to ten minutes after the animal has played a chukker, characterising thus the post-exercise time, i.e., final time $\left(\mathrm{M}_{\mathrm{f}}\right)$.

Electrocardiographic tracings were obtained for 60 seconds (C10 TEB, software ECGPC Veterinary 2.27), where bipolar leads I, II, III, augmented unipolar leads aVR, aVF, aVL as well as V4 and V10 precordial leads were recorded. Electrodes were placed according to the bipolar lead system of Dubois, XEG (xiphoid process of the sternum/left scapula) and XED (xiphoid process of the sternum/right scapula). As for precordial leads, V4 was fixed in the sixth left intercostal space below the costochondral junction and V10 on the spinous process of the seventh thoracic vertebra. We evaluated ECGs by a qualified veterinary, for only cardiac arrhythmias and features of fatigue to include changes in ST and QTc segments, and $\mathrm{T}$ wave morphology.

$M$ mode echocardiography was performed from a right parasternal window, to obtain the left ventricular internal diameter in systole (LVIDs) and diastole (LVIDd), thickness of the interventricular septum in systole (IVSs) and left ventricular free wall in systole (LVFWs), following the guidelines of the American Society of Echocardiography. Echocardiography was performed with a Sonosite Elite Plus ${ }^{\circledR}$, and convex broadband transducer of 2-4 MHz with a range of $25 \mathrm{~cm}$ depth.

Echocardiographic evaluation was restricted to indexes previously reported to represent cardiac fatigue. The shortening fraction (SF) was calculated from the values obtained from LVIDd and LVIDs with the formula: SF= [(LVIDd-LVIDs)/LVIDd] x 100. The end-systolic volume of the left ventricle (SVLV) and the end-diastolic volume of the left ventricle (DVLV) were determined by the formula modified by Teicholz: [7 x (DLV) ${ }^{3} / 2.4+$ DLV] (DLV - Diameter left ventricle). Ejection fraction (EF) was obtained by the formula [DVLV-SVLV)/DVLV] $\mathrm{x}$ 100. Finally, the stroke volume (SV) was obtained by the difference between DVLV and SVLV.

In order to evaluate the loss of body weight, a portable scale was utilised with an adapted platform (TOLEDO MGR-3000 Jr $\left.{ }^{\circledR}\right)$. Data were obtained before exercise $\left(M_{0}\right)$ and after exercise $\left(\mathrm{M}_{\mathrm{f}}\right)$, when all animals were without riding accessories. Immediately prior to weighing, they had no access to water or any type of food.

\section{STATISTICAL ANALYSIS}

Data obtained at $\mathrm{M}_{0}$ and $\mathrm{M}_{\mathrm{f}}$ was tested for normality by the Kolmogorov-Sminov test, followed by the paired Student's t-test for parametric data, or Wilcoxon test for nonparametric data. Pearson correlations were also performed. For all statistical analyses, a significance threshold of $\mathrm{P} \leq$ 0.05 was utilized. Data were presented as mean and standard deviation (GraphPad Prism 6.02 for Windows, GraphPad Software, San Diego, CA, USA).

\section{RESULTS}

\section{BODY MASS}

Body weight loss after exercise may indirectly expresses the fluid loss through sweat, and was on average $1.54 \%$ after a chukker (table 1).

\section{ELECTROCARDIOGRAPHIC DATA}

In this study, we observed only one case of ventricular ectopy, that was identified as three single ventricular premature complexes (VPC). The same animal that presented ventricular ectopy, also had an increase in T-wave amplitude $(\mathrm{M} 0=1.09 \mathrm{mV}, \mathrm{Mf}=2.52 \mathrm{mV})$, the highest increase among all animals examined and a significant increase in QTc $(\mathrm{M} 0=373 \mathrm{~s}, \mathrm{Mf}=470 \mathrm{~s})$.

The QT interval, corrected by heart rate (QTc) was increased (reached $458.08 \mathrm{~ms}$ ) in Mf (table 1), and similar 
Table 1. Representation of QTc electrocardiographic index and body weight of polo horses before and after exercise.

Representación del índice eletrocardiográfico QTc y peso corporal de equinos de polo, antes y después del ejercicio.

\begin{tabular}{|c|c|c|}
\hline \multirow{2}{*}{ Index } & \multicolumn{2}{|c|}{$\mathrm{Md} \pm \mathrm{SD}$} \\
\hline & $\mathrm{M}_{0}$ & $\mathrm{M}_{\mathrm{f}}$ \\
\hline Duration of QTc (ms) & $382.54 \pm 27.27^{\mathrm{a}}$ & $458.08 \pm 32.44^{\mathrm{a}}$ \\
\hline Weight $(\mathrm{Kg})$ & $427.21 \pm 29.77$ & $420.63 \pm 32.73$ \\
\hline
\end{tabular}

$\mathrm{ms}=$ millisecond, $\mathrm{Kg}=$ kilograms, $\mathrm{Md}=$ mean, $\mathrm{SD}=$ standard deviation, $\mathrm{M}_{0}=$ before the exercise, $\mathrm{M}_{\mathrm{f}}=$ after the exercise. Values with ${ }^{\mathrm{a}}$ superscript in the same row are statistically different.

$\mathrm{ms}=$ mili segundo, $\mathrm{Kg}=$ Kilogramos, $\mathrm{Md}=$ media, $\mathrm{SD}=$ desvio estándar, $\mathrm{M}_{0}=$ antes del ejercício, $\mathrm{M}_{\mathrm{f}}=$ despues del ejercício. Valores con superíndices ${ }^{\mathrm{a}}$ en una misma línea son estadisticamente diferentes.

change was observed in the ST segment, which showed an increase above $0.3 \mathrm{mV}$ in $8 \%$ of horses after the polo game. Increased single positive T-wave amplitude was observed after exercise, although it was not statistically evaluated due to its variation in relation to the number of animals (figure 1). Polarity reversal of T-wave was also observed among this group of polo horses (figure 2).

\section{ECHOCARDIOGRAPHIC DATA}

The echocardiogram results demonstrated reduced left ventricular function represented by reduced values in the following echocardiographic parameters: IVSs $(-5.1 \%$, $\mathrm{P}<0.05)$, LVFWs $(-20.8 \%, \mathrm{P}<0.05)$, SV $(-19.5 \%, \mathrm{P}<$ $0.05), \mathrm{SF}(-22.5 \%, \mathrm{P}<0.05)$ and $\mathrm{EF}(-15.1 \%, \mathrm{P}<0.05)$ after the polo game in healthy horses (table 2 ).

\section{DISCUSSION}

Cardiac arrhythmias in horses are difficult to interpret since they may be present before, during and/or after
Table 2. Representation of ecocardiographic indices of polo horses before and after exercise.

Representación de índices ecocardiográficos de equinos de polo, antes y después del ejercicio de polo.

\begin{tabular}{lcc}
\hline \multirow{2}{*}{ Index } & $\mathrm{Md} \pm \mathrm{SD}$ & $\mathrm{Md} \pm \mathrm{SD}$ \\
\cline { 2 - 3 } & $\mathrm{M}_{0}$ & $\mathrm{M}_{\mathrm{f}}$ \\
\hline IVSs (cm) & $4.28 \pm 0.35^{\mathrm{a}}$ & $4.06 \pm 0.40^{\mathrm{a}}$ \\
LVIDs (cm) & $5.91 \pm 0.81^{\mathrm{a}}$ & $6.66 \pm 0.75^{\mathrm{a}}$ \\
LVFWs (cm) & $3.74 \pm 0.51^{\mathrm{a}}$ & $2.96 \pm 0.51^{\mathrm{a}}$ \\
LVIDd (cm) & $9.74 \pm 0.86$ & $9.60 \pm 0.15$ \\
SV (ml) & $2139.27 \pm 556.21^{\mathrm{a}}$ & $1722.41 \pm 487.66^{\mathrm{a}}$ \\
SF (\%) & $39.45 \pm 5.29^{\mathrm{a}}$ & $30.58 \pm 5.58^{\mathrm{a}}$ \\
EF (\%) & $77.06 \pm 6.29^{\mathrm{a}}$ & $65.43 \pm 8.22^{\mathrm{a}}$ \\
HR (bpm) & $35.70 \pm 6.27^{\mathrm{a}}$ & $77.41 \pm 15.418^{\mathrm{a}}$ \\
\hline
\end{tabular}

Values with a superscript in the same row are statistically different. Interventricular septum thickness in systole (IVSs); left ventricular internal diameter in systole (LVIDs); thickness of the free wall of the left ventricle in systole (LVFWs); left ventricular internal diameter in diastole (LVIDd); systolic volume (SV); shortening fraction (SF); ejection fraction (EF); heart rate (HR), $M_{0}=$ before the exercise, $M_{f}=$ after the exercise. Valores con superíndices ${ }^{a}$ en una misma línea son estadisticamente diferentes. Espesor del septo interventricular en sístole (IVSs); diámetro interno del ventrículo izquerdo en sístole (LVIDs); espesor de la pared libre del ventrículo izquerdo en sístole (LVFWs); diámetro interno del ventrículo izquerdo en diástole (LVIDd); volumen sistólico (SV); fracción de acortamiento (SF); fracción de eyección (EF); frequencia cardíaca (HR), $\mathrm{M}_{0}=$ antes del ejercício, $\mathrm{M}_{\mathrm{f}}=$ despues del ejercício.

exercise without any associated cardiac disease. For Ryan et al (2005), the occurrence of ventricular premature complexes (VPC) and supraventricular premature complexes (SPC) before exercise was relatively common in clinically normal horses. In this study, we observed only one case of VPCs that was repeated three times on the same tracing. The cause of this arrhythmia was not determined, however according to Marr and Bowen (2010) could be associated with hypoxia, ischemia, electrolyte and metabolic disorders, or pre-existing heart disease, such as myocarditis.

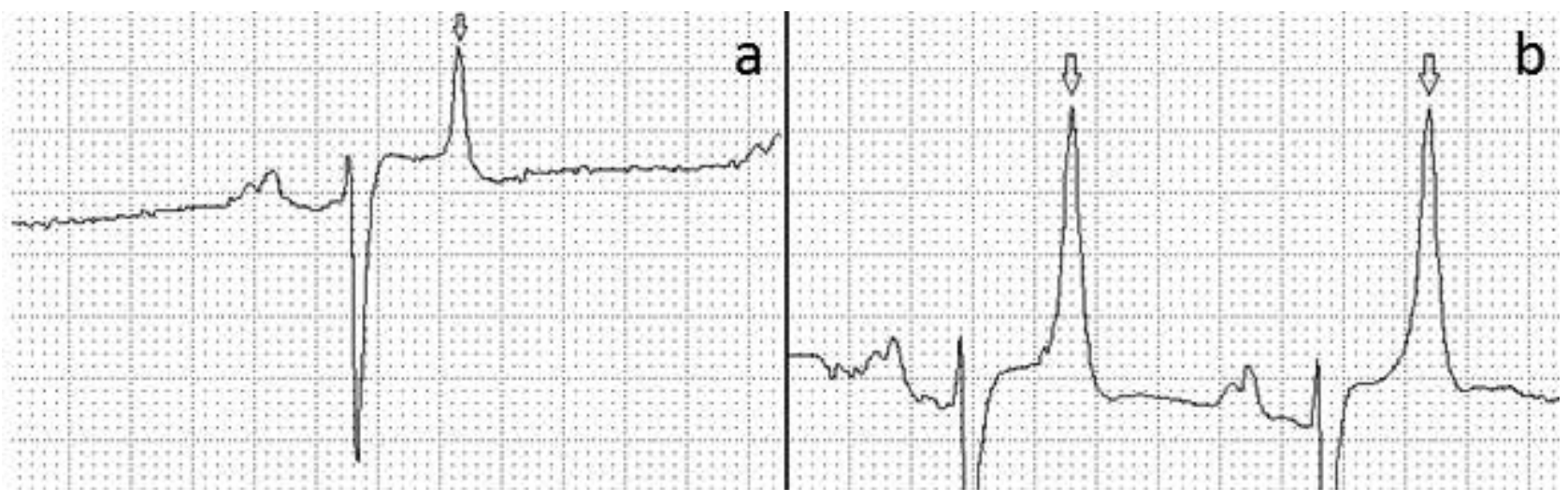

Figure 1. Electrocardiogram in the II bipolar lead, at $25 \mathrm{~mm} / \mathrm{s}$ of a polo horse presenting a marked increase in the single positive T-wave amplitude highlighted by the arrows. (a) is the result before the pole exercise $\left(\mathbf{M}_{0}\right)$, and (b), after the exercise $\left(\mathrm{M}_{\mathrm{f}}\right)$.

Trazado eletrocardiográfico en la derivación bipolar II, en velocidad de $25 \mathrm{~mm} / \mathrm{s}$ de un equino de polo presentando un aumento marcado de la amplitud de onda $T$ única positiva destacados por las flechas. Se considera a (a) como el resultado antes del ejercicio de polo $\left(\mathrm{M}_{0}\right)$ y $(\mathbf{b})\left(\mathrm{M}_{\mathrm{f}}\right)$ después del ejercicio de polo. 


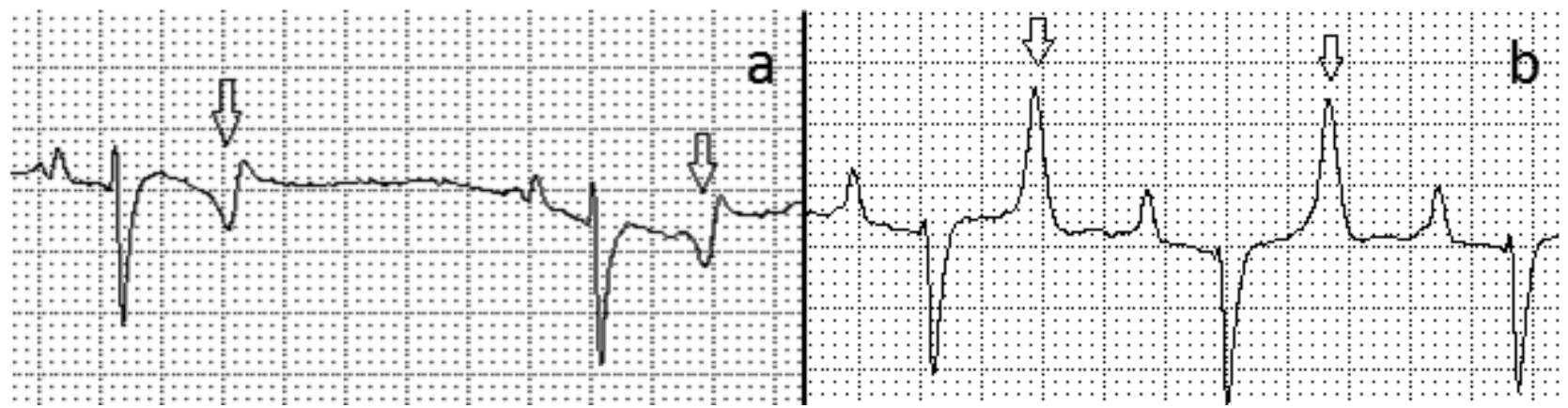

Figure 2. Eletrocardiogram in the II bipolar lead, at $25 \mathrm{~mm} / \mathrm{s}$ of a horse before (a) and after (b) the polo exercise. Arrows indicate the change in T-wave morphology between the two periods evaluated.

Trazado eletrocardiográfico en la derivación bipolar II, en velocidad de $25 \mathrm{~mm} / \mathrm{s}$ de un equino antes (a) y después (b) del ejercicio de polo. Las flechas indican el cambio de morfología de la onda $\mathrm{T}$ entre los dos momentos evaluados.

Also according to these authors, when the arrhythmia was associated with exercise, a complete evaluation of other organ systems is indicated, in an attempt to identify the arrhythmia's etiology or to detect multifactorial problems. Persistence of arrhythmias, either during or immediately after exercise, justifies determination of a poor prognosis, because the circulatory efficiency is of paramount importance during these events.

The polo game increased QTc interval, this finding was previously reported by Dumont et al (2011) in horses after a $90 \mathrm{~km}$ endurance competition, and they suggested the occurrence of mild and transient cardiac fatigue, since this index returned to normal after rest. Dumont et al (2011) considered that the increased QTc interval was directly proportional to myocardial fatigue, which can reach $550 \mathrm{~ms}$ in cases of excessive fatigue and remain between $450 \mathrm{~ms}$ and $500 \mathrm{~ms}$ in mild fatigue. Using this scale, we confirmed mild myocardial fatigue in these polo horses, as the QTc reached $458.08 \mathrm{~ms}$ after the training match. In humans, an increased QTc interval (longer than 660ms) was considered to be a predisposing factor for the development of ventricular arrhythmias and is associated with sudden cardiac death in cases of long QT syndrome. Thus, we suggest, for polo horses of the present study, that this mild myocardial fatigue finding may be associated with the occurrence of electrolyte disturbances such as hypokalemia, hypomagnesemia and hypocalcemia, or underlying disease, acute myocarditis, pericarditis or other unknown causes.

Increase single positive T-wave amplitude was observed after polo exercise. T-wave changes are associated with systemic physiological and pathological conditions including physical exertion, excitement, drug use, infectious diseases, vagal tone, electrolyte disturbances, hypoxia and myocarditis (Rose et al 1979). The T-wave is highly labile and can be influenced by a large number of different factors making the quantification and determination of this finding extremely difficult. Among the major changes in T-waves observed in horses with altered athletic performance are polarity reversal and increased amplitude (Rose et al 1979).
The same animal that presented VPCs, also had the highest increase in T-wave amplitude. These findings indicated that this animal was not fit to safely perform the required effort, possibly presenting some subclinical or clinical undiagnosed disorder.

ST segment elevation greater than $0.3 \mathrm{mV}$ was detected in this study, and this abnormality was previously reported in endurance horses disqualified for exhaustion (Dumont et al 2011). ST segment elevation is classically considered an electrocardiographic marker of myocardial ischemia. Insufficient conditioning and exhausting effort performed by animals can be the cause of ST segment elevation and our data suggests that these horses, even being of low handicap, were not adequately trained. Additionally conditions such as hypokalemia, excessive sudden effort, marked volume overload, hyperventilation and left ventricular hypertrophy are some of the non-coronary causes for ST segment elevation reported in human athletes (Negrão and Barreto 2010) that were not thoroughly excluded in our study.

In the present study, the echocardiogram results showed reduced left ventricular function after the polo game, with reduction in myocardial thickness during systole, this suggest that myocardial contractility was compromised, because according to Marr and Bowen (2010), the left ventricular function should increase with exercise-induced sympathetic stimulation, causing increased thickness of IVSs during systole. We also observed a reduction in $\mathrm{SV}$, coinciding with that mentioned by Bello et al (2011) for endurance horses, they considered that this reduction observed immediately after exercise was indicative of the exercise-induced cardiac fatigue.

We verify that SF was also reduced immediately after polo game. According to Douglas et al (1987) and Evans (2004) this reduction would be related to the exercise intensity, and it would be higher among those with the lowest times during the race, since this parameter indicated the quality of cardiac contractility. Thus, the reduction of SF to Kalliokoski et al (2004) was a sign of cardiac fatigue. Another common method for assessing systolic function was the analysis of the ventricular EF, which represented in 
general the performance of the left ventricle (Boon 1998). Quantitatively in horses after exercise on a treadmill, it was verified that the ventricular EF has decreased in comparison with basal values, which signifies the occurrence of depressed left ventricular function after exercise (Schefer et al 2010), and was also observed in animals of this study.

Body weight loss expresses indirectly the fluid loss through sweat; in this study we found variations of up to 9\% weight loss. Similarly, Ferraz et al (2010) observed acute changes in electrolytes and acid-base balance after pole training match. Thus one must consider the supply of high quality water to animals of utmost importance. Principally a rest period between two matches should be respected, even in horse of a low handicap such as these study subjects. Nevertheless, the accuracy regarding the time required for the animals to replenish fluids and electrolytes lost during the exercise should be evaluated in future studies.

It can be concluded that by means of electrocardiogram and echocardiogram it was possible to observe that practicing polo leads to cardiac fatigue in healthy horses. However, it was not possible to accurately establish the etiology of this change, and its consequences. Other studies are warranted to characterize the duration and long-term consequences of cardiac fatigue in polo horses.

\section{REFERENCES}

Amory H, DM Votion, A Fraipont, AG Goachet, C Robert, F Farnir, E Van Erck. 2010. Altered systolic left ventricular function in horses completing a long distance endurance race. Eq Vet J 42, 216-219.

Bello CAO, CES Vasconcelos, RF Godoy, AR Teixeira-neto, JRJ Borges, EMM Lima. 2011. Ecocardigrafia de equinos Puro Sangue árabe após exercício de enduro de diSFrentes intensidades. Ciênc Rural 41, 132-136.
Boon JA. 1998. Evaluation of size, function and hemodynamics. In: Manual of Veterinary Echocardiography. Williams \& Wilkins, Baltimore, USA, Pp 151-260.

Douglas PS, ML O’Toole, WD Hiller, K Hackney, N Reichek. 1987. Cardiac fatigue after prolonged exercise. Circ 76, 1206-1213.

Dumont CBS, JM Moraes, CR Leite, RO Alves, M Moreira, ARC Moscardini, RF Godoy, EMM Lima. 2011. Parâmetros eletrocardiográficos de equinos desclassificados por exaustão em competições de enduro. Arq Bras Med Vet Zootec 63, 20-27.

Evans D. 2004. Exercise testing in the field. In: Hinchcliff KW, AJ Kaneps, RJ Geor (eds). Equine Sports Medicine and Surgery. Saunders, London, UK, Pp 9-18.

Ferraz GC, OA Soares, NS Foz, MC Pereira, A Queiroz-Neto. 2010. The workload and plasma ion concentration in a training match session of high-goal (elite) polo ponies. Eq Vet J 42, 191-195.

Holbrook T, EK Birks, MM Sleeper, M Durando. 2006. Endurance exercise is associated with increased plasma cardiac troponin I in horses. $E q$ Vet J Suppl 36, 27-31.

Kalliokoski KK, MS Laaksonen, M Luotolahti, H Laine, TO Takala, P Nuutila, J Knuuti. 2004. Myocardial perfusion after marathon running. Scand J Med Sci Sports 14, 208-214.

Marlin D, J Allen. 1999. Cardiovascular demands of competition on lowgoal (non-elite) polo ponies. Eq Vet J Suppl 31, 378-382.

Marr CM, IM Bowen. 2010. Cardiology of the Horse. $2^{\text {nd }}$ ed. Saunders, London, UK.

McGavock JM, DE Warburton, D Taylor, RC Welsh, HA Quinney, MJ Haykowsky. 2002. The effects of prolonged strenuous exercise on left ventricular function: a brief review. Heart Lung 31, 279-292.

Negrão CE, ACP Barreto. 2010. Cardiologia do Exercício: do Atleta ao Cardiopata. $3^{\text {ed }}$. Manole São Paulo, Brasil.

Rose RJ, JE Ilkiw, D Hodgdon. 1979. Electrocardiography, heart score and haematology of horses competing in an endurance ride. Aust Vet $J 55,247-250$.

Ryan N, CM Marr, AJ McGladdery. 2005. Survey of cardiac arrhythmias during submaximal and maximal exercise in Thoroughbred racehorses. Eq Vet J 37, 265-268.

Schefer KD, C Bitschnau, MA Weishaupt, CC Schwarzwald. 2010. Quantitative analysis of stress echocardiograms in healthy horses with 2-dimensional (2d) echocardiography, anatomical m-mode, tissue doppler imaging, and 2d speckle tracking. J Vet Inter Med 24, 918-931. 